\title{
QUANTITATIVE ANALYSIS OF GENETIC IMPROVEMENT OF MILK PRODUCTION PHENOTYPES IN SIMMENTAL COWS**
}

\author{
M.M. Petrović ${ }^{1 *}$, Lj.Sretenović1, V. Bogdanović², P. Perišićc ${ }^{2}$, S.

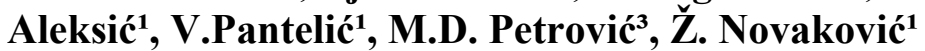

\author{
${ }^{1}$ Institute for Animal Husbandry, Belgrade - Zemun, 11080 Zemun \\ ${ }^{2}$ Faculty of Agriculture, Belgrade \\ ${ }^{3}$ Faculty of Agronomy, Čačak \\ *Corresponding author: Milan M.Petrović, e-mail: milpet99@yahoo.com \\ **Originalni naučni rad - Original scientific paper \\ Research financed by the Ministry of Science and Technological Development, Republic of \\ Serbia, Project 20042-TR
}

Abstract: Results of the effect of direct and indirect selection on quantitative properties of milk production of first calving Simmental cows in Serbia, are presented in the paper. Analysis of quantitative phenotypic parameters was carried out in four breeding regions and certain number of smaller farms where 1319 daughters of 13 bull sires were reared. Results of the analysis were obtained by application of mathematical-statistical data analysis, using mixed models (Harvey, 1990). Mathematical-statistical analysis of data was carried out using linear methods with fixed effect, through method of least squares (LS method), and for evaluation of bull breeding value mixed model of random bull sire effect was used (BLUP method).

Based on obtained results it was established that analyzed breeding region has statistically highly significantly $(* * \mathrm{P}<0.01$.) caused deviations of production phenotypes from general average. Season and year of calving (* $\mathrm{P}<0.05$.) have caused significant variations of production properties.

Key words: cow, milk, breeding value, rank, bull sire, BLUP

\section{Introduction}

Cows of Simmental breed are reared in Serbia in semi-intensive housing, care and nutrition conditions, i.e. on smaller farms with few heads of cattle to farms with tens of female animals in intensive system of housing, care and nutrition. 
Genetic improvement of Simmental cattle in our country is realized through selection, i.e. breeding in pure breed. There was to some extent introduction of genes of Red Holstein breed for the purpose of improvement of milk production and milk ability. Improvement of genetic basis of population of Simmental cattle in our conditions is realized through bull sires, i.e. semen deriving from Germany, Austria and some other countries. Evaluation of the additive value of genotype, i.e. accuracy of its evaluation (breeding value of bulls) is directly related to the effect of selection in cattle population. Tendency is towards more accurate and objective evaluation of the breeding value, which is in our country carried out mainly by comparison of females of the same age (CC method), and recently also using BLUP method.

Investigation of production traits of Simmental cows, the effect of systematic factors on these traits and evaluation of breeding value were studied by Lazarević et al. (1986),, Petrović et al. (1997 and 2006), Petrović et al. (2005) and Pantelić et al.(2008).

\section{Material and methods}

Data collected and used in analysis derives from four regions - breeding regions in Serbia. Investigation included 1319 first calving cows of Simmental breed which had calved in the period of four years (2004 - 2007), and evaluation/score of breeding value of 13 bull sires.

Breeding regions are: Šumadija (1), Pomoravlje (2), Rasina (3), Braničevo (4). First (I) calving season was in the months of February, March and April, the second (II) calving season in May, June and July, the third (III) calving season in August, September and October, and fourth (IV) season in November, December and January. Bull sires were of Simmental breed and used by two Livestock-veterinary centers in Republic of Serbia.

All investigated heads (cows) were kept in tie or free system and owned by private farmers, nutrition was usual, and differences were in the quantity, ratio and quality of forage and concentrated feeds (breeding region).

Mathematical-statistical data analysis was done using mixed model of least squares with fixed and random effects (LS-Least Squares and BLUP-Best Linear Unbiased Prediction), and program of least squares (LSMLMW), Harvey, 1990. In analysis of the effect of breeding region, year and season of calving, bull sires on phenotypes of milk yield in cows in first lactation, following models were used:

$$
\begin{aligned}
& \text { 1. } Y_{i j k l}=\mu+P_{i}+G_{j}+S_{k}+G_{1}+b_{1}\left(x_{1}-x_{1}\right)+e_{i j k l m} \\
& 2 . Y_{i j k l}=\mu+P_{i}+G_{j}+S_{k}+O_{1}+e_{i j k l m}
\end{aligned}
$$


where:

$\mathrm{Y}_{\mathrm{ijklm}}$ - individual animal $(\mathrm{m})$, reared in i region, calved in $\mathrm{j}$ year and $\mathrm{k}$ season and deriving from 1 bull sire

$\mu$ - general average of the population

$\mathrm{P}_{\mathrm{i}}$ - fixed effect of breeding region (1-4)

$\mathrm{G}_{\mathrm{j}}$ - fixed effect of year of calving (1-4)

$\mathrm{S}_{\mathrm{k}}$ - fixed effect of season of calving (1-4)

$\mathrm{GS}_{1}-$ fixed effect of interaction year/season

$\mathrm{O}_{1}$ - random effect of bull sire (1-13)

$\mathrm{b}_{1}$ - linear regression effect of age at calving

$\mathrm{e}_{\mathrm{ijklm}}-$ other undetermined effects

For obtaining of BLUP solutions values of coefficient of interclass correlation of $\mathrm{R}=0.30$ were used.

\section{Results and discussion}

First calving cows included in our research produced $4868 \mathrm{~kg}$ milk, i.e. $3.76 \%$ of milk fat and $4693 \mathrm{~kg}$ FCM. Quantitative milk traits of cows under the influence of breeding region had very significant deviation from general average (** $\mathrm{P}<0.01)$, (tab.1).

Considerable deviation $(\mathrm{P}<0.05)$ were caused by year of calving on milk yield and yield of milk fat. Season of the year when the lactation of cows included in our research started showed highly significant deviation of milk yield and yield of milk fat compared to general average $(\mathrm{P}<0.01)$. So, heifers which had calved in February, March and April had highly significantly more milk and milk fat in relation to those who calved in other months of the year. Interaction of the breeding region and calving season caused significant deviations of the milk yield $(* * \mathrm{P}<0.01)$, however, there were no statistically significant variations of the content of milk fat.

Rank of bull sires and their random effect on milk traits of thirteen groups of half sisters is presented in table 2. Based on analysis of negative and positive BLUP solutions (breeding values) for yield of 4\%FCM rank was formed according to which bull number 13 had the best score and bull 9 was scored last. 
Table 1. Least - Squares analysis of variance (F exp)

\begin{tabular}{|l|c|c|c|c|}
\hline Influences & Milk,kg & Milk fat,kg & Milk fat, $\%$ & $4 \% \mathrm{FCM}, \mathrm{kg}$ \\
\hline Breeding area & $10.541^{* *}$ & $11.675^{* *}$ & $22.654^{* *}$ & $11.879^{* *}$ \\
\hline Year of calving & $3.765^{*}$ & $3.999^{*}$ & $-.765^{\mathrm{NS}}$ & $2.876^{*}$ \\
\hline $\begin{array}{l}\text { Season of } \\
\text { calving }\end{array}$ & $3.432^{*}$ & $3.986^{*}$ & $3.321^{* *}$ & $3.122^{*}$ \\
\hline $\begin{array}{l}\text { Breeding area } \\
\text { /Season of } \\
\text { calving } \\
\text { (interaction) }\end{array}$ & $3.543^{* *}$ & $3.234^{* *}$ & $1.542^{\mathrm{NS}}$ & $3.876^{* *}$ \\
\hline
\end{tabular}

$\mathrm{NS}=\mathrm{P}>0.05 \quad *=\mathrm{P}<0.05 \quad * * \mathrm{P}<0.01$

Results obtained in our research are higher compared to results on milk yield of the same breed (Lazarevic et al., 1986), and considerably higher compared to results obtained by Vasović (1991), higher than results established by Petrović et al. (1997 and 2006). Our results are similar to those obtained by Petrović et al. (2005) and Pantelić et al. (2008). Results obtained in this research showed that there is positive genetic trend in the sense of quantitative milk traits of Simmental cows. By comparison of our results and results presented by mentioned authors it can be concluded that milk yield of Simmental cows (main herd) in Serbia increases each year by at least $100 \mathrm{~kg}$ of milk per cow (depending on the genetics, region and housing/rearing technology and nutrition).

Table 2. Breeding Value Evaluation (BV) and Rank of Bull Sires (RB)

\begin{tabular}{|c|c|c|c|c|}
\hline Bull No. & No. of daughters & Milk fat, $\%$ & $4 \% \mathrm{FCM}, \mathrm{kg}$ & Rank of Bulls \\
\hline 1 & 101 & -.02 & 152.72 & 5 \\
\hline 2 & 96 & -.15 & -201.03 & 10 \\
\hline 3 & 117 & .01 & 59.66 & 7 \\
\hline 4 & 69 & -.03 & 198.80 & 4 \\
\hline 5 & 58 & .01 & 619.53 & 2 \\
\hline 6 & 87 & .04 & -203.26 & 11 \\
\hline 7 & 131 & -.07 & -410.85 & 12 \\
\hline 8 & 68 & .08 & 426.56 & 3 \\
\hline 9 & 162 & .01 & -694.23 & 13 \\
\hline 10 & 118 & -.09 & -102.77 & 9 \\
\hline 11 & 56 & -.02 & 99.62 & 6 \\
\hline 12 & 107 & .05 & 10.43 & 8 \\
\hline 13 & 149 & .01 & 709.81 & 1 \\
\hline
\end{tabular}




\title{
Conclusion
}

Results of the effect of direct and indirect selection on quantitative properties of milk production of first calving Simmental cows in Serbia are presented in the paper. Analysis of quantitative phenotypic parameters was carried out in four breeding regions and certain number of smaller farms where 1319 daughters of 13 bull sires were reared. Results of the analysis were obtained by application of mathematical-statistical data analysis, using mixed models (Harvey, 1990). Mathematical-statistical analysis of data was carried out using linear methods with fixed effect, through method of least squares (LS method), and for evaluation of bull breeding value mixed model of random bull sire effect was used (BLUP method).

Based on obtained results it was established that breeding region had statistically highly significant effect $(* * \quad \mathrm{P}<0.01$.) on production phenotypes causing deviation from the general average. Season and year of calving (* $\mathrm{P}<0.05$.) caused significant variations of production traits.

First calving cows included in our research had produced $4868 \mathrm{~kg}$ of milk, i.e. $3.76 \%$ of milk fat and $4693 \mathrm{~kg} 4 \% \mathrm{FCM}$. Results of deviations of phenotypes of milk traits under the effect of breeding region were highly significant $(* * \mathrm{P}<0.01)$. Our results showed the presence of positive genetic trend in sense of quantitative traits of milk yield in domestic Simmental cows. By comparison of our results and results presented by other authors it can be concluded that milk yield of Simmental cows (main herd) in Serbia increases each year by at least $100 \mathrm{~kg}$ of milk per cow (depending on the genetics, region and housing/rearing technology and nutrition).

\section{KVANTITATIVNA ANALIZA GENETSKOG UNAPREĐENJA FENOTIPOVA MLEČNOSTI KRAVA SIMENTALSKE RASE}

\author{
M.M. Petrović, Lj.Sretenović, V. Bogdanović, P. Perišić, S. Aleksić, \\ V.Pantelić, M.D. Petrović, Ž. Novaković
}

\section{Rezime}

U radu su prikazani rezultati efekata direktne i indirektne selekcije kvantitativnih svojstava mlečnosti krava-prvotelki simentalske rase goveda u Srbiji. Analiza kvanitativnih fenotipskih parametara je obavljena u četiri odgajivačka područja i na više desetina manjih farmi na kojima je držano i 
gajeno 1319 kćeri, 13 bikova-očeva. Rezultati analize su dobijeni primenom matematičko-statističke analize podataka, korišćenjem mešovitih modela (Harvey, 1990). Matematičko-statistička analiza podataka je obavljena korišćenjem linearnih metoda sa fiksnim uticajem, preko metoda najmanjih kvadrata (LS metod) a za ocenu priplodne vrednosti bikova korišćen je mešoviti model slučajnog uticaja oca (BLUP metod).Na osnovu dobijenih rezultata ustanovljeno je da je odgajivačko područje statistički analizirano visoko značajno (** $\mathrm{P}<0.01$.) prouzrokovalo odstupanja proizvodnih fenotipova od opšteg proseka. Sezona telenja i godina $(* \mathrm{P}<0.05$.) su prouzrokovali značajna variranja proizvodnih osobina. Rezultati odstupanja osobina proizvodnosti pod uticajem godine telenja ukazuju na pozitivne tendencije u povećanju prinosa mleka . Značajna odstupanja $(\mathrm{P}<0.05)$ je izazvala godina telenja i na prinos mleka i mlečne masti. Godišnje doba početka laktacije krava obuhvaćenih našim istraživanjem pokazuje visokoznačajna odstupanja prinosa mleka i mlečne masti $u$ odnosu na opšti prosek $(\mathrm{P}<0.01)$. Tako su junice oteljene $u$ februaru, martu i aprilu imale značajno i visoko značajno više mleka i mlečne masti $u$ odnosu na one koje su se otelile u drugim mesecima u godini. Interakcija odgajivačkog područja i sezone telenja je prouzrokovala visoko značajna odstupanja prinosa mleka $(* * \mathrm{P}<0.01)$, međutim nije bilo statističkih značajnih variranja sadržaja mlečne masti.

Prema analizi negativnih i pozitivnih BLUP rešenja (priplodne vrednosti) za prinos 4\%MKM formirana je ocena ranga prema kojoj je bik broj 13. najbolje ocenjen, a bik-otac br.9 bio je rangiran na poslednje mesto.

Krave - prvotelke obuhvaćene našim istraživanjem proizvele su 4868 $\mathrm{kg}$ mleka sa $183.03 \mathrm{~kg}$ mlečne masti, odnosno $3.76 \%$ mle. mast i $4693 \mathrm{~kg}$ 4\%MKM . Rezultati dobijeni nasim istraživanjima su značajno viši u odnosu na rezultate o mlečnosti iste rase (Lazarevic R. i sar ., 1986). viši od onih koje je ustanovio Petrovic M.M. i sar. (1997 i 2006). Dobijeni rezultati su u saglasnosti sa onima koje su dobili Petrović M.D. i sar. (2005) i Pantelić i sar.(2008). Naši rezultati su pokazali da postoji pozitivan genetski trend $u$ smislu kvantitaivnih osobina mlečnosti domaćih somentalskih krava. Poredeći naše rezultate i rezultate napred navedenih autora može se zaključiti da se prinos mleka simentalskih krava (matični zapat) u Srbiji godišnje uvećava za najmanje $100 \mathrm{~kg}$ mleka po kravi (zavisno od genetike, područja, odnosno tehnologija ishrane i držanja). 


\section{References}

HARWEY W.R.(1990): Mixed Model Least Squares and Maximum Likelihood Computer Program. User, s Gguide for LSML MW and MIXMDL.

LAZAREVIĆ R., MILOJIĆ M., NIKITOVIĆ N., VASOVIĆ S., TRIFUNOVIĆ G: (1986): Unapređenje proizvodnje mleka u matičnim zapatima simentalskih krava. Stočarstvo,9-10,p.279-284.

PANTELIĆ, V., PETROVIĆ, M.M., ALEKSIĆ, S., SRETENOVIĆ, LJ., OSTOJIĆ'ANDRIĆ, D., NOVAKOVIĆ, Ž. (2008): Investigation of the Genetic Correlation Between Milk and Fertility Traits of First Calving Cows of Simmental Breed.Biotehnology in Animal Husbandry, 24(5-6), p.1 - 8. PETROVIĆ, M.M., LAZAREVIČ R., LAZAREVIĆ LJ., ALEKSIĆ, S., MIŠČEVIĆ, B., PERKOVIĆ S (1997): Proizvodni efekti selekcije aktivne populacije simentalskih goveda u Srbiji. Biotehnology in Animal Husbandry, 13, (3-4), p.57- 64 .

PETROVIĆ, D.M., SKALICKI, Z., BOGDANOVIĆ, V., PETROVIĆ, M.M., KURČUBIĆ, V. (2005): The Effect of Paragenetic Factors on Performance Traits in Complete Lactations in Simmental Cows. Biotechnology in Animal Husbandry, 21(5-6), p.7 - 12.

PETROVIĆ, M.M., SRETENOVIĆ, LJ., PANTELIĆ, V., ALEKSIĆ, S., MIŠČEVIĆ, B., BOGDANOVIĆ, V., OSTOJIĆ'ANDRIĆ, D. ,PETROVIĆ,M. (2006): Results of the Application of the Technology of Genetic Improvement of Simmental Cattle Population in Serbia. Biotechnology in Animal Husbandry, 22(1-2), p.1-8. 